\title{
RENDEMEN KITOSAN LIMBAH CANGKANG KERANG SIMPING (Amusium pleuronectes) DAN KERANG KEPAH (Polymesoda erosa) DARI KENDAL JAWA TENGAH
}

\author{
Ariyanti Ariyanti*, Eni Masruriati, \\ Arin Widya Nuari, M. Himawan Yoga Syahputra \\ Program studi Farmasi Sekolah Tinggi Ilmu Kesehatan Kendal, Kendal 51311 \\ *Email : riri99.cettaazzahra@gmail.com
}

\section{INTISARI}

Kitosan merupakan hasil dari proses deasetilasi dari kitin dengan cara menghilangkan gugus asetil sehingga didapatkan senyawa polimer dan glukosamin. Pemanfaatan kitosan yang berasal dari limbah cangkang kerang simping (Amusium pleuronectes) dan cangkang kerang kepah (Polymesoda erosa) belum maksimal. Penelitian ini bertujuan untuk mengetahui rendemen kitosan pada limbah cangkang kerang simping dan cangkang kerang kepah.

Metode yang digunakan dalam penelitian ini adalah metode isolasi deasetilasi dengan lima kali replikasi. Hasil kadar rendemen dianalisis univariate dan bivariate dengan spps 19.0 menggunakan t-test.

Berdasarkan hasil penelitian sampel limbah cangkang kerang simping dan limbah cangkang kerang kepah memiliki rendemen kitosan tertinggi pada konsentrasi $\mathrm{NaOH} 75 \%$ b/v yaitu 6,972 $\% \mathrm{~b} / \mathrm{v}$ untuk limbah cangkang kerang simping dan 5,972\%b/v limbah cangkang kerang kepah. Hasil penelitian didapat konsentrasi $\mathrm{NaOH} 15,25,50$, dan $75 \% \mathrm{~b} / \mathrm{v}$ dapat mempengaruhi perubahan kitin menjadi kitosan dari limbah cangkang kerang simping dan cangkang kerang kepah.

Kata kunci: Amusium pleuronectes, Polymesoda erosa, deasetilasi, kitin, kitosan

\section{ABSTRACT}

Chitosan is the result of the deacetylation process of chitin by removing acetyl groups to obtain polymer compounds and glucosamine. Utilization of chitosan derived from waste of Amusium pleuronectes and Polymesoda erosa has not been maximize. This study aims to determine the highest chitosan yield in Amusium pleuronectes and Polymesoda erosa.

The method used in this study was a deacetylation isolation method with five replications. The yield of the yield content was analyzed by univariate and bivariate with spps 19.0 using a $t$ test.

Based on the results of the research on the sample of Amusium pleuronectes and Polymesoda erosa, the highest yield of chitosan at $75 \% \mathrm{~b} / \mathrm{v}$ concentration of $\mathrm{NaOH}$ was $6,972 \%$ $b / v$ for Amusium pleuronectes and 5.972\% b/v for Polymesoda erosa. The results showed that $\mathrm{NaOH}$ concentrations of $15 \mathrm{v}, 25,50$, and $75 \% \mathrm{~b} / \mathrm{v}$ could affect the chitin change to chitosan against Amusium pleuronectes and Polymesoda erosa.

Keywords: Amusium pleuronectes, Polymesoda erosa, deacetylation, chitin, chitosan

*Corresponding author:

Ariyanti

Program Studi Sarjana Farmasi STIKES Kendal, Kendal 51311

Email : riri99.cettaazzahra@gmail.com 


\section{PENDAHULUAN}

Kabupaten Kendal memiliki hasil laut yang cukup melimpah. Hasil laut menjadi salah satu komoditas terbanyak (Nontji, 1993). Hasil laut di Kabupaten Kendal yang banyak dimanfaatkan adalah kerang dan ikan. Kerang merupakan hewan laut khas karena dilapisi cangkang yang keras. Cangkang kerang merupakan bahan sumber mineral yang pada umumnya berasal dari hewan laut berupa kerang yang telah mengalami penggilingan dan mempunyai karbonat tinggi. Kandungan yang terdapat dalam cangkang kerang adalah $\mathrm{CaO}, \mathrm{SiO}_{2}, \mathrm{Fe}_{2} \mathrm{O}_{3}, \mathrm{MgO}$ dan $\mathrm{Al}_{2} \mathrm{O}_{3}$ (Marito, 2009). Kelimpahan cangkang kerang di Kabupaten Kendal karena biasanya hanya dimanfaatkan dagingnya, sedangkan cangkangnya menjadi limbah. Penelitian ini adalah sebagai bentuk memaksimalkan hasil laut. Limbah cangkang kerang dapat diolah untuk mendapatkan kitosan. Isolasi limbah cangkang kerang dilakukan dengan cara deasetilasi, yaitu proses penghilangan gugus asetil $\left(\mathrm{COCH}_{3}\right)$ dari kitin menggunakan larutan alkali. Kitosan adalah polimer yang banyak dimanfaatkan dalam bidang farmasi, kesehatan, kosmetik, makanan sebagai bahan tambahan misalnya sebagai pengawet.

Menurut Patil dan Deshpande (2000), kitin merupakan biopolimer tersusun oleh unit-unit $\mathrm{N}$-asetil-D-glukosamin berikatan $\beta(1-4)$ yang paling banyak dijumpai di alam setelah selulosa, sedangkan kitosan merupakan senyawa hasil deasetilasi kitin, terdiri dari unit $\mathrm{N}$-asetil glukosamin dan $\mathrm{N}$ glukosamin. Struktur kitosan merupakan gugus reaktif amino atom C-2 dan gugus hidroksil pada atom C-3 dan C-6. Berdasarkan uraian tersebut peneliti tertarik untuk mengisolasi kitin dari limbah cangkang kerang simping dan limbah cangkang kerang kepah dari Rowosari, Kendal menjadi kitosan dengan metode deasetilasi sehingga rendemen kitosan dapat diketahui.

\section{METODE PENELITIAN}

\section{Bahan Penelitian}

Bahan yang digunakan pada penelitian ini adalah limbah cangkang kerang simping dan kepah, larutan $\mathrm{NaOH} 3 \%, \mathrm{HCl} 1,25 \mathrm{~N}$, larutan $\mathrm{NaOH} 15,25,50,75 \% \mathrm{~b} / \mathrm{v}$ dan Aquadest.

\section{Alat Penelitian}

Alat yang digunakan pada penelitian ini adalah neraca analitik, oven, blender, pengayak, bunsen dan kaki tiga, termometer, indikator $\mathrm{pH}$, erlenmeyer, gelas ukur, beaker glass, corong kaca, cawan porselin dan kaca arloji.

\section{Jalannya Penelitian}

\section{Penyiapan bahan baku}

Cangkang kerang simping dan kepah mula-mula dicuci dengan air mengalir untuk membersihkan kotoran-kotoran yang melekat. Proses pengeringan di bawah sinar matahari selama 8-12 jam atau dalam oven dengan suhu $80^{\circ} \mathrm{C}$ selama 24 jam sehingga diperoleh produk kering dengan kadar air $\pm 10 \%$. Setelah kering limbah cangkang kerang kemudian dihaluskan dan diayak dengan menggunakan ayakan nomer 60 untuk mendapatkan ukuran partikel yang akan digunakan $( \pm 3 \mathrm{~mm})$.

\section{Ekstraksi dan isolasi kitin}

a. Deproteinisasi

Limbah cangkang kerang simping dan kepah masing-masing ditimbang kemudian dicampur dengan $\mathrm{NaOH} 3 \%$ dengan perbandingan 1:5. Campuran tersebut kemudian dipanaskan pada suhu $60-70^{\circ} \mathrm{C}$ selama dua jam. Larutan didinginkan dan disaring sehingga didapat padatan. Padatan dicuci dengan air sampai $\mathrm{pH}$ netral, kemudian dikeringkan pada suhu $60^{\circ} \mathrm{C}$ selama 36 jam (Pujiastuti, 2001 dan Suhardi, 1993).

b. Demineralisasi

Menurut Pujiastuti (2001) dan Suhardi (1993), limbah cangkang kerang simping dan cangkang kerang kepah yang telah melewati proses deproteinisasi dicampur dengan $\mathrm{HCl}$ $1,25 \mathrm{~N}$ dengan perbandingan $1: 5$, lalu dipanaskan pada suhu $70-75^{\circ} \mathrm{C}$ selama dua jam. Larutan kemudian disaring sehingga didapat padatan, lalu dicuci dengan air sampai $\mathrm{pH}$ netral. Padatan kemudian dikeringkan dalam oven pada suhu $60^{\circ} \mathrm{C}$ selama 36 jam. Kitin yang dihasilkan disimpan dalam kantong plastik untuk siap digunakan. 
c. Deasetilasi kitin menjadi kitosan

Menurut Pujiastuti (2001) dan Suhardi (1993), kitin yang diperoleh ditambah $\mathrm{NaOH}$ konsentrasi $15,25,50$, dan 75\% b/v dengan perbandingan 1:5, lalu dipanaskan pada suhu 70$75^{\circ} \mathrm{C}$ selama dua jam. Larutan kemudian disaring sehingga didapat padatan, lalu dicuci dengan air sampai $\mathrm{pH}$ netral. Padatan kemudian dikeringkan dalam oven pada suhu $60^{\circ} \mathrm{C}$ selama 36 jam. Kitosan yang diperoleh ditimbang dan disimpan dalam kantong plastik pada suhu kamar.

\section{Perhitungan rendemen}

Kitosan yang diperoleh kemudian ditimbang, dan dihitung rendemennya dari perbandingan bobot kitosan dengan bobot bahan baku kering.

\section{Analisis Data}

Data dianalisis univariate kadar rendemen kitosan dan menurut Hidayat dan Istiadah (2011), analisa data yang dilakukan dengan skala ukur rasio menggunakan statistik. Analisa data dilakukan dengan menggunakan metode SPSS 19.0.

\section{HASIL DAN PEMBAHASAN} tabel I.

Rendemen kitin dari limbah cangkang kerang simping dan kerang kepah dapat dilihat pada

Tabel I. Rendemen kitin dari limbah cangkang kerang simping dan kerang kepah

\begin{tabular}{ccc}
\hline \multirow{2}{*}{ Rep. } & \multicolumn{2}{c}{ Rendemen Kitin (\%) } \\
\cline { 2 - 3 } & $\begin{array}{c}\text { Limbah Cangkang Kerang } \\
\text { Simping }\end{array}$ & $\begin{array}{c}\text { Limbah Cangkang Kerang } \\
\text { Kepah }\end{array}$ \\
\hline 1 & 88,23 & 78,45 \\
2 & 88,36 & 78,48 \\
3 & 88,32 & 78,49 \\
4 & 88,36 & 78,47 \\
5 & 88,34 & 78,44 \\
Rata-rata & 88,32 & 78,46 \\
\hline
\end{tabular}

Sampel cangkang kerang simping menghasilkan rendemen kitin lebih tinggi yaitu 88,32\% dibandingkan rendemen kitin yang diperoleh dari cangkang kerang kepah yaitu 78,46\%. Hal ini disebabkan cangkang kerang simping lebih besar dan lebar dibandingkan dengan cangkang kerang kepah.

Rendemen kitosan dari limbah cangkang kerang simping dan kerang kepah dapat dilihat pada tabel II.

Tabel II. Rendemen kitosan dari limbah cangkang kerang simping dan kerang kepah

\begin{tabular}{ccc}
\hline \multirow{2}{*}{ Kadar Konsentrasi } & \multicolumn{2}{c}{ Rendemen Kitosan (\%) } \\
\cline { 2 - 3 } & $\begin{array}{c}\text { Limbah Cangkang Kerang } \\
\text { Simping }\end{array}$ & $\begin{array}{c}\text { Limbah Cangkang } \\
\text { Kerang Kepah }\end{array}$ \\
\hline \multirow{2}{*}{$\mathrm{NaOH} 15 \%$} & 6,55 & 5,34 \\
& 6,54 & 5,44 \\
& 6,53 & 5,36 \\
& 6,54 & 5,40 \\
Rata-rata & 6,55 & 5,43 \\
\hline & 6,54 & 5,39 \\
\hline & 6,63 & 5,63 \\
& 6,63 & 5,64 \\
& 6,62 & 5,65 \\
& 6,64 & 5,65 \\
& 6,62 & 5,64 \\
\hline Rata-rata & 6,63 & 5,64
\end{tabular}




\begin{tabular}{ccc}
\hline & 6,73 & 5,76 \\
$\mathrm{NaOH} 50 \%$ & 6,75 & 5,78 \\
& 6,74 & 5,76 \\
& 6,75 & 5,77 \\
& 6,73 & 5,78 \\
\hline Rata-rata & 6,74 & 5,78 \\
\hline & 6,98 & 5,97 \\
$\mathrm{NaOH} 75 \%$ & 6,97 & 5,99 \\
& 6,96 & 5,97 \\
& 6,97 & 5,95 \\
& 6,98 & 5,98 \\
\hline Rata-rata & 6,97 & 5,97 \\
\hline
\end{tabular}

Sampel cangkang kerang simping menunjukkan adanya peningkatan rendemen kitosan pada setiap kenaikan konsentrasi $\mathrm{NaOH}$. Pada konsentrasi $\mathrm{NaOH}$ tertinggi yaitu $75 \% \mathrm{~b} / \mathrm{v}$ menunjukkan rendemen kitosan tertinggi yaitu rata-rata 6,97\%, sedangkan pada konsentrasi $\mathrm{NaOH} 15 \% \mathrm{~b} / \mathrm{v}$ nilai rata-rata rendemen adalah $6,54 \%$. Hasil yang sama juga ditunjukkan pada sampel limbah cangkang kerang kepah yang menunjukkan peningkatan rendemen kitosan pada setiap kenaikan konsentrasi $\mathrm{NaOH}$. Pada konsentrasi $\mathrm{NaOH} 75 \% \mathrm{~b} / \mathrm{v}$ memiliki rendemen kitosan rata-rata tertinggi yaitu 5,97\%, sedangkan pada konsentrasi $\mathrm{NaOH} 15 \% \mathrm{~b} / \mathrm{v}$ memiliki rendemen kitosan terendah dengan nilai ratarata $5,39 \%$.

Menurut Pujiastuti (2001), banyaknya kitosan yang diperoleh disebabkan proses deasetilasi yang tergantung suhu dan lama proses deasetilasi. Derajat deasetilasi kitosan meningkat dengan meningkatnya waktu dan suhu deasetilasi. Dalam penelitian ini waktu dan suhu proses deasetilasi yang digunakan sama pada kedua sampel cangkang kerang, sehingga perbedaan rendemen kitosan dari keduanya disebabkan perbedaan rendemen kitin yang diperoleh dari proses demineralisasi.

Analisis univariate dan bivariate dari nilai rendemen kitosan baik dari limbah cangkang kerang simping maupun kerang kepah dapat dilihat pada tabel III dan tabel IV.

Tabel III. Analisis data univariate rendemen kitosan dari limbah cangkang kerang simping dan cangkang kerang kepah

\begin{tabular}{lccc}
\hline \multicolumn{1}{c}{ Sampel } & N & Mean & Std. Deviasi \\
\hline Limbah cangkang kerang simping & 20 & 6,52 & 0,14 \\
Limbah cangkang kerang kepah & 20 & 5,52 & 0,15 \\
\hline
\end{tabular}

Analisis univariate dilakukan untuk kadar rendemen kitosan karena dari cangkang kerang kemudian diubah menjadi kitin menggunakan $\mathrm{HCl}$ pada konsentrasi yang sama. Sedangkan pada proses deasetilasi kitin menjadi kitosan menggunakan $\mathrm{NaOH}$ pada 4 konsentrasi yang berbeda. Analisis data univariate adalah analisis satu variabel atau per variabel sehingga kesalahan koding atau entry data dapat diketahui. Nilai $\mathrm{N}$ adalah jumlah perlakuan sebanyak 20 kali. Nilai rata-rata (mean) limbah cangkang kerang simping lebih besar dibandingkan limbah cangkang kerang kepah dengan simpangan baku (standar deviasi) relatif kecil. Menurut Patil dan Deshpande (2000), proses deasetilasi yang merupakan proses penghilangan gugus asetil $\left(\mathrm{COCH}_{3}\right)$ dari kitin menggunakan larutan alkali. Proses deasetilasi masing-masing kitin dari limbah cangkang kerang memberikan hasil kitosan yang berbeda karena dipengaruhi oleh jenis kerang.

Menurut Hidayat dan Istiadah (2011), analisis data dapat dilakukan dengan skala ukur rasio menggunakan statistik. Independent sample test digunakan untuk menganalisis apakah perbedaan rata-rata nilai rendemen kitosan tersebut nyata atau tidak bisa dilakukan dengan leavene test dan $t$ test. Pengujian varian dengan Leavene test menguji apakah varian populasi kedua sampel sama atau berbeda. Tabel IV menunjukkan nilai F hitung yaitu 3,51 dengan nilai probabilitas 0,14 . Analisis bivariate rendemen kitosan, independent samples test juga digunakan untuk menganalisis apakah perbedaan rata-rata nilai rendemen kitosan tersebut nyata atau tidak bisa dilakukan dengan leavene 
test dan t-test. Nilai probabilitas $>0,05$ maka $\mathrm{H}_{0}$ diterima atau kedua varians tidak berbeda bermakna. Sedangkan pada uji t-test nilai t didapat 5,23 dengan nilai probabilitas 0,00. Nilai probabilitas $<0,05$ maka $\mathrm{H}_{0}$ ditolak atau kedua rata-rata rendemen kitosan antara limbah cangkang kerang simping dan cangkang kerang kepah adalah berbeda signifikan.

Tabel IV. Analisis data bivariate independent samples test rendemen kitosan limbah cangkang kerang simping dan cangkang kerang kepah

\begin{tabular}{llcccc}
\hline & & \multicolumn{3}{c}{$\begin{array}{c}\text { Levene's Test for } \\
\text { Equality of Variances }\end{array}$} & t-test for Equality of Means \\
\cline { 2 - 6 } & F & Sig. & t & Sig. (2-tailed) \\
\hline $\begin{array}{l}\text { Kadar } \\
\text { Rendemen } \\
\text { Kitosan }\end{array}$ & $\begin{array}{l}\text { Equal variances } \\
\text { assumed }\end{array}$ & 3,51 & 0,14 & 5,23 & 0,00 \\
$\begin{array}{l}\text { Equal variances not } \\
\text { assumed }\end{array}$ & & & 5,45 & 0,00 \\
\hline
\end{tabular}

\section{KESIMPULAN}

1. Sampel cangkang kerang simping mempunyai kadar rendemen kitin lebih tinggi yaitu $88,32 \%$ dibandingkan kadar rendemen kitin pada kerang kepah yaitu 78,46\%.

2. Terdapat perbedaan signifikan antara rendemen kitosan dari limbah cangkang kerang simping dan cangkang kerang kepah karena perbedaan rendemen kitin.

\section{DAFTAR PUSTAKA}

Nontji, A., 1993, Laut Nusantara (Nusantara Sea), Jakarta: Djambatan

Marito, S.S., 2009, Pemanfaatan Cangkang kerang Dan Resin Epoksi Terhadap Karakteristik Beton Polimer, Tesis, Universitas Sumatera Utara, Medan.

Patil, R.S., dan Deshpande, M., 2000, Chitinolytic enzymes an exploration, Enz Microb Technol, 26:473-483.

Pujiastuti, P., 2001, Kajian transformasi khitin menjadi khitosan secara kimiawi dan enzimatik, Prosiding, Seminar Nasional Jurusan Kimia FMIPA UNS, Surakarta.

Suhardi, 1993, Khitin dan Khitosan, Pusat Antar Universitas pangan dan Gizi, PAU UGM, Yogyakarta.

Hidayat, T., dan Istiadah, N., 2011, SPSS 19, Cetakan I, 10-11, Mediakita, Jakarta. 